\title{
Cerium oxide nanoparticles: green synthesis and biological applications
}

This article was published in the following Dove Press journal:

International Journal of Nanomedicine

20 February 2017

Number of times this article has been viewed

\author{
Fahimeh Charbgoo' \\ Mansor Bin Ahmad 2,* \\ Majid Darroudi3,* \\ 'Department of Pharmaceutical \\ Biotechnology, School of Pharmacy, \\ Mashhad University of Medical \\ Sciences, Mashhad, Iran; ${ }^{2}$ Department \\ of Chemistry, Faculty of Science, \\ Universiti Putra Malaysia, Serdang, \\ Selangor, Malaysia; ${ }^{3}$ Nuclear Medicine \\ Research Center, Mashhad University \\ of Medical Sciences, Mashhad, Iran \\ *These authors contributed equally \\ to this work
}

\begin{abstract}
CeO}_{2}$ nanoparticles (NPs) have shown promising approaches as therapeutic agents in biology and medical sciences. The physicochemical properties of $\mathrm{CeO}_{2}-\mathrm{NPs}$, such as size, agglomeration status in liquid, and surface charge, play important roles in the ultimate interactions of the NP with target cells. Recently, $\mathrm{CeO}_{2}-\mathrm{NPs}$ have been synthesized through several bio-directed methods applying natural and organic matrices as stabilizing agents in order to prepare biocompatible $\mathrm{CeO}_{2}-\mathrm{NPs}$, thereby solving the challenges regarding safety, and providing the appropriate situation for their effective use in biomedicine. This review discusses the different green strategies for $\mathrm{CeO}_{2}$-NPs synthesis, their advantages and challenges that are to be overcome. In addition, this review focuses on recent progress in the potential application of $\mathrm{CeO}_{2}$-NPs in biological and medical fields. Exploiting biocompatible $\mathrm{CeO}_{2}-\mathrm{NPs}$ may improve outcomes profoundly with the promise of effective neurodegenerative therapy and multiple applications in nanobiotechnology.
\end{abstract}

Keywords: cerium oxide nanoparticles, green synthesis, biocompatibility, surface $\mathrm{Ce}^{3+}$, size, morphology

\section{Introduction}

$\mathrm{CeO}_{2}$ nanoparticles (NPs) have received much attention in nanotechnology due to their useful applications as catalysts, fuel cells and antioxidants in biological systems. ${ }^{1-5}$ In general, cerium can exist in two oxidation states: $\mathrm{Ce}^{3+}$ and $\mathrm{Ce}^{4+}$. Therefore, cerium dioxide can have two different oxide forms, $\mathrm{CeO}_{2}\left(\mathrm{Ce}^{4+}\right)$ or $\mathrm{Ce}_{2} \mathrm{O}_{3}\left(\mathrm{Ce}^{3+}\right)$, in bulk material. ${ }^{4,6} \mathrm{On}$ the nanoscale, the cerium oxide lattice has a cubic fluorite structure, and both $\mathrm{Ce}^{3+}$ and $\mathrm{Ce}^{4+}$ can coexist on its surface. Charge deficiency due to the presence of $\mathrm{Ce}^{3+}$ is compensated by oxygen vacancy in the lattice; thus, $\mathrm{CeO}_{2}-\mathrm{NPs}$ contain intrinsic oxygen defects. ${ }^{7}$ These oxygen defects are actually sites of catalytic reactions. The concentration of oxygen defects increases with reduction in particle size. ${ }^{8}$ Therefore, $\mathrm{CeO}_{2}$-NPs have improved redox properties with respect to the bulk materials. Moreover, the presence of a mixed valance state plays an important role in scavenging reactive oxygen and nitrogen species. $\mathrm{CeO}_{2}-\mathrm{NPs}$ are found to be effective against pathologies associated with chronic oxidative stress and inflammation. Recently, $\mathrm{CeO}_{2}$-NPs have also been reported to have multienzyme, including superoxide oxidase, catalase and oxidase, and mimetic properties, and have emerged as a fascinating material in biological fields, such as in bioanalysis, ${ }^{9-14}$ biomedicine ${ }^{15}$ and drug delivery. ${ }^{16,17}$ These applications are derived from quick transition of the oxidation state between $\mathrm{Ce}^{3+}$ and $\mathrm{Ce}^{4+} .6$ The surface $\mathrm{Ce}^{3+}: \mathrm{Ce}^{4+}$ ratio is influenced by the microenvironment. Therefore, the microenvironment and synthesis method adopted also plays an important role in determining the biological activity and toxicity of 
$\mathrm{CeO}_{2}$-NPs. The $\mathrm{CeO}_{2}$-NPs have been prepared through the means of several routes and synthesis methods including solution precipitation, ${ }^{18}$ sonochemical, ${ }^{19}$ hydrothermal, ${ }^{20}$ solvothermal, ${ }^{21}$ ball milling, ${ }^{22}$ thermal decomposition, ${ }^{23}$ spray pyrolysis, ${ }^{24}$ thermal hydrolysis ${ }^{25}$ and sol-gel methods. ${ }^{26-28}$ However, applying the mentioned methods deals with several drawbacks, such as toxic solvents and reagents usage, high temperature and pressure, and the requirement of external additives as stabilizing or capping agents during the reaction. As the physiochemical properties of NPs mostly depend on the synthesis procedure, the synthesis method of NPs for biological applications is very important. The physical properties (size, surface charge, agglomeration status in liquid and coating or residual contamination of the surfactant on the surface) of NPs mainly influence interactions at the nano-bio interface ${ }^{29}$ Moreover, the surface $\mathrm{Ce}^{3+}: \mathrm{Ce}^{4+}$ ratio (chemical property) also influences the biocatalysis and the biological interactions. Manipulation of the surface $\mathrm{Ce}^{3+}: \mathrm{Ce}^{4+}$ ratio can be achieved by controlling their synthesis method. ${ }^{30}$ However, coating the NPs with biocompatible/organic polymers increases dispersion/stability, decreases nonspecific interactions with cells and proteins, increases blood circulation time and reduces the toxicity of the NPs. ${ }^{31}$

Biomaterials possess functional groups such as $-\mathrm{COOH}$, $-\mathrm{OH}$ and $-\mathrm{NH}_{2}$, and have the potential to stabilize and/or cap metal ions for preparation of various NPs via green chemistry methods. Recently, $\mathrm{CeO}_{2}$-NPs have been synthesized through several bio-directed methods applying natural and organic matrices as stabilizing agents in order to prepare biocompatible $\mathrm{CeO}_{2}$-NPs and solve the challenges to safely and effectively use this metal oxide for biomedicinal purposes. ${ }^{27,28,32}$ In the first part of the review, we discuss the literature on different green synthesis methods of $\mathrm{CeO}_{2}$-NPs (Table 1). Next, we discuss the effect of these $\mathrm{CeO}_{2}$-NPs on reducing their cytotoxicity in the biological environment. Finally, a brief review on the updates of the potential biological application of $\mathrm{CeO}_{2}-\mathrm{NPs}$ is presented.

\section{Green approaches for $\mathrm{CeO}_{2}-\mathrm{NP}$ synthesis Plant-mediated synthesis of $\mathrm{CeO}_{2}-\mathrm{NPs}$}

Phytosynthesis of metal and metal oxide NPs is a new emerging issue in nanoscience and technology ${ }^{33}$ Recently, phytosynthesis of $\mathrm{CeO}_{2}$-NPs was reported using different plants, such as Gloriosa superba, Acalypha indica and even Aloe vera plant leaf extract (Figure 1). ${ }^{33-35}$ The plant extracts acted as stabilizing and capping agents in the $\mathrm{CeO}_{2}$-NPs synthesis process. Investigating biological effects of the phytosynthesized NPs, antibacterial activity of them was examined. The results showed that smaller crystal sizes with a higher surface area led to higher antibacterial activity. These reports applied bio-directed methods of $\mathrm{CeO}_{2}-\mathrm{NP}$ synthesis. However, the synthesized nanoparticles were generally so large in size

Table I Green synthesis methods of $\mathrm{CeO}_{2}-\mathrm{NPs}$

\begin{tabular}{|c|c|c|c|c|c|}
\hline Method of green synthesis & $\begin{array}{l}\text { Applied material/ } \\
\text { organism }\end{array}$ & $\begin{array}{l}\text { Particle } \\
\text { size }(\mathrm{nm})\end{array}$ & $\begin{array}{l}\text { Morphology } \\
\text { of NPs }\end{array}$ & Critical point of view & Reference \\
\hline Plant-mediated synthesis & Gloriosa superba & 5 & Spherical & $\begin{array}{l}\text { Different kinds of alkaloids acted as } \\
\text { stabilizing agents }\end{array}$ & 33 \\
\hline Plant-mediated synthesis & Acalypha indica & 36 & Spherical & $\begin{array}{l}\text { Agglomeration of particles were } \\
\text { observed due to covalent bonding } \\
\text { of the individual particles }\end{array}$ & 34 \\
\hline Plant-mediated synthesis & Aloe vera & 63.6 & Spherical & & 35 \\
\hline Fungus-mediated synthesis & Curvularia lunata & $5-20$ & Spherical & $\begin{array}{l}\text { Enzymes, proteins and heterocyclic } \\
\text { derivatives could act as reducing } \\
\text { and capping agent }\end{array}$ & 37 \\
\hline Nutrient-mediated synthesis & EW protein & $\begin{array}{l}8.2,11.7 \\
\text { and } 17.3\end{array}$ & Spherical & $\begin{array}{l}\text { Being soluble and foam-like in } \\
\text { water, EW has several proteins } \\
\text { acting as stabilizing agents }\end{array}$ & 47 \\
\hline Nutrient-mediated synthesis & Honey & 23 & Spherical & Follow-up the sol-gel method & 48 \\
\hline Biopolymer-mediated synthesis & Agarose & 10.5 & Spherical & Follow-up the sol-gel method & 51 \\
\hline Biopolymer-mediated synthesis & Starch & 6 & Spherical & Providing ultrafine product & 27 \\
\hline Biopolymer-mediated synthesis & Gum & 10 & Spherical & & 27 \\
\hline Biopolymer-mediated synthesis & Dextran & 5 & Spherical & $\mathrm{pH}$-dependent response & 57 \\
\hline Biopolymer-mediated synthesis & Polyethylene glycol & $\sim 2$ & Spherical & $\begin{array}{l}\text { Providing a framework for designing } \\
\text { a hybrid metal oxide sol }\end{array}$ & 58 \\
\hline Biopolymer-mediated synthesis & Chitosan & $\sim 10$ & Spherical & $\begin{array}{l}\text { Applicable in food borne } \\
\text { mycoplasma detection }\end{array}$ & 61 \\
\hline
\end{tabular}

Abbreviations: EW, egg white; NPs, nanoparticles. 


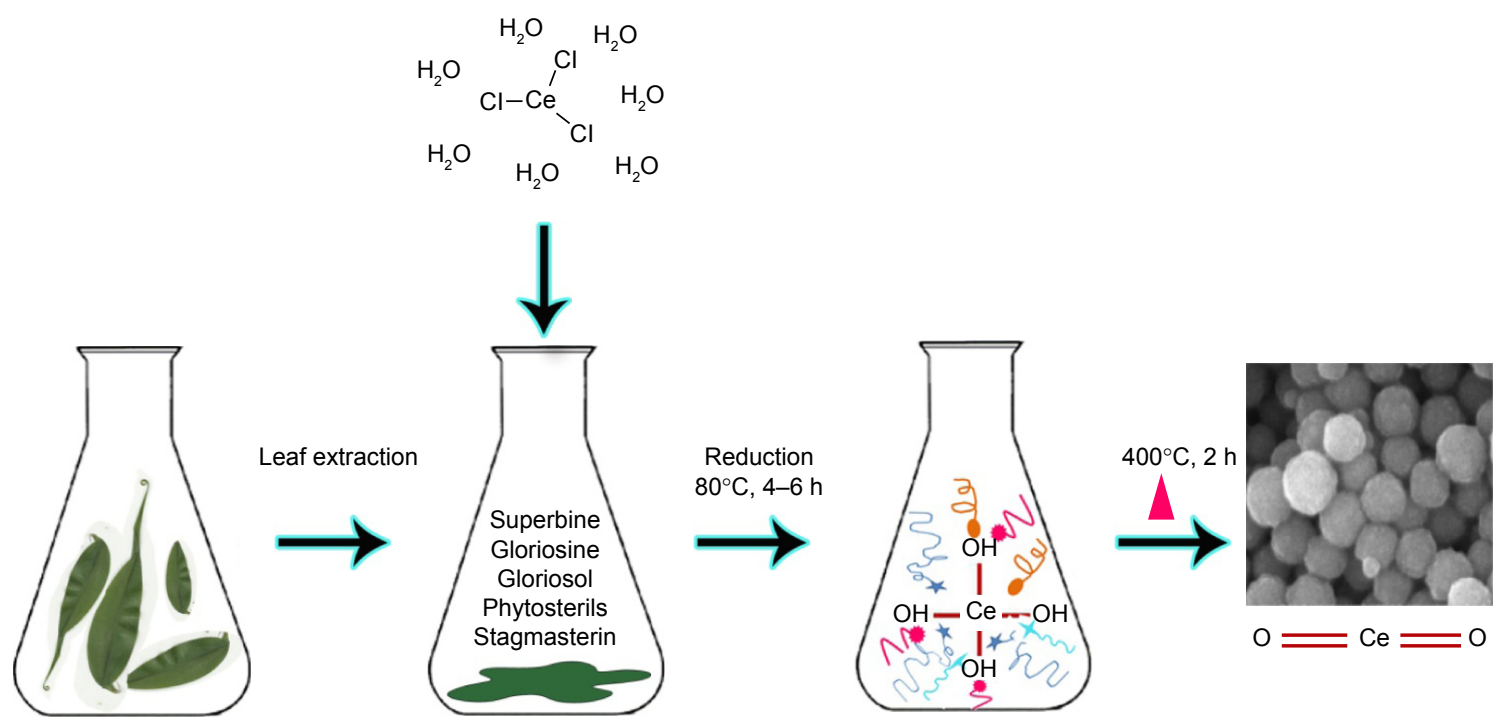

Figure I Schematic representation of Gloriosa superba-based method of cerium oxide nanoparticle synthesis.

that, according to literature, they were not appropriate for biomedical applications. ${ }^{1,36}$ Recently, biosynthesis of NPs using yeast and fungi has also been noted. Munusamy et al had explained rapid and extracellular synthesis of cerium oxide NPs using fungus Curvularia lunata culture media. ${ }^{37}$ The synthesized NPs had a cubic structure and exhibited antibacterial effects against different kinds of bacteria. ${ }^{37}$ It is known that $\mathrm{CeO}_{2}-\mathrm{NPs}$ cannot enter bacterial and algal cells. Noninternalized $\mathrm{CeO}_{2}-\mathrm{NPs}$ seem to show toxic effects by direct attachment of $\mathrm{CeO}_{2}$-NPs to cell walls of algae and bacteria. ${ }^{38-41}$ Several mechanisms have been suggested to demonstrate how $\mathrm{CeO}_{2}$-NPs in contact with the membrane may exert cytotoxicity. $\mathrm{CeO}_{2}-\mathrm{NPs}$ could interfere with the nutrient transport functions of the membrane, ${ }^{39}$ cause mechanical damage and membrane disruption ${ }^{42,43}$ or generate reactive oxygen species (ROS) and induce oxidative stress. ${ }^{38-40}$ The generation of ROS, most probably hydrogen peroxide, by $\mathrm{CeO}_{2}$-NPs is in agreement with observations noted by Xia et al ${ }^{44}$ and Zhao et al ${ }^{45}$ Hydrogen peroxide is capable of freely diffusing across cell walls and membranes, inducing cell damage.

Consequently, myco-synthesis of $\mathrm{CeO}_{2}$-NPs showed advantages including manageability, cost-effectiveness, and used techniques that were less time-consuming and required less energy, ${ }^{46}$ and therefore can be used as an economic and valuable alternative for the large-scale production of $\mathrm{CeO}_{2}$-NPs. Moreover, myco-synthesized $\mathrm{CeO}_{2}$-NPs had more stability, water dispersibility and high fluorescent properties. The fungal extracellular compounds, such as proteins (especially enzymes), and heterocyclic derivatives could act as reducing and capping agents. Other methods of plant-based $\mathrm{CeO}_{2}$-NPs synthesis were also easy, rapid and cost-effective, but the size of obtained NPs exhibited a wide distribution range, which demonstrates that the necessity of optimizing the biosynthesis methods mentioned earlier in order for application in biological systems.

\section{Nutrient-mediated synthesis of $\mathrm{CeO}_{2}-\mathrm{NPs}$}

As mentioned, synthetic methods determine the size, charge, surface properties, solubility and morphology of NPs, therefore affecting response of $\mathrm{CeO}_{2}$-NPs in biological systems. That is why green synthesis of $\mathrm{CeO}_{2}-\mathrm{NPs}$ has received much attention recently. Several studies widely reported different nutrients and natural materials, such as egg white (EW) protein and honey for $\mathrm{CeO}_{2}$-NPs green synthesis. ${ }^{47,48} \mathrm{Kargar}$ et $\mathrm{al}{ }^{47}$ proposed that the two major proteins of EW, ovalbumin and lysozyme, acted as a green binders/stabilizing agents for the preparation of $\mathrm{CeO}_{2}-\mathrm{NPs}$. The general mechanism for synthesizing $\mathrm{CeO}_{2}-\mathrm{NPs}$ in EW media includes formation of the electrostatic interaction between cerium cations $\left(\mathrm{Ce}^{3+}\right)$ and oppositely charged proteins which leads to controllable growth and subsequent isotropic formation of small and stable $\mathrm{CeO}_{2}-\mathrm{NPs}^{47,49}$ Some of the green methods of $\mathrm{CeO}_{2}-\mathrm{NP}$ preparation mimic the common traditional approaches in NP synthesis in a safe and eco-friendly way. ${ }^{48}$ For example, honey-based synthesis of $\mathrm{CeO}_{2}$-NPs mimics the sol-gel method. The extensive number of carbohydrates, enzymes and vitamins containing hydroxyl and amine groups in the honey matrix structure can facilitate the complexation of 
cerium cations $\left(\mathrm{Ce}^{3+}\right)$ to an initial molecular matrix. Therefore, honey was capable of coating and stabilizing cerium species and $\mathrm{CeO}_{2}$-NPs while inhibiting their excessive aggregation or crystal growth. ${ }^{48}$ However, advancement of the EW-based method for $\mathrm{CeO}_{2}-\mathrm{NP}$ green synthesis is obvious due to nontoxic effects of $\mathrm{CeO}_{2}$-NPs at concentrations up to $800 \mu \mathrm{g} / \mathrm{mL}$, compared with the safe concentration of $\sim 25 \mu \mathrm{g} / \mathrm{mL}$ for honey-based $\mathrm{CeO}_{2}$-NPs. Therefore, the synthesis of $\mathrm{CeO}_{2}$-NPs in EW was found to be an excellent alternative for the preparation of $\mathrm{CeO}_{2}-\mathrm{NPs}$, using food and bio-derived materials.

\section{Biopolymer-mediated synthesis of $\mathrm{CeO}_{2}-$ NPs}

Natural polymers in the form of macromolecules can also be used as templates for bio-directed synthesis of $\mathrm{CeO}_{2}$-NPs. As the surface of the NPs could be covered by hydroxyl groups, biopolymers that intrinsically possess hydroxyl moieties are capable of stabilizing $\mathrm{CeO}_{2}-\mathrm{NPs}_{\text {s }}$ Applying the polymers as capping/stabilizing agents, the diameter of NPs can be logically controlled. ${ }^{50}$ Kargar et al reported the green synthesis of small cerium oxide NPs, stabilized with agarose polymers via a sol-gel method. ${ }^{51}$ While heating to $>90^{\circ} \mathrm{C}$, the agarose powder is normally dissolved in water, and when the temperature is reduced to $35^{\circ} \mathrm{C}-40^{\circ} \mathrm{C}$, semisolid gel is formed that is stable over a wide $\mathrm{pH}$ range of (from 3 to 9 ). Interpenetrating $\mathrm{H}$-binding between sugar moieties resulted in production of this sol-gel network and nanochannel containing pore sizes of $200 \mathrm{~nm}$. $\mathrm{CeO}_{2}$-NPs were synthesized in these nanochannels. Similarly, Darroudi et al had synthesized $\mathrm{CeO}_{2}-\mathrm{NPs}$ using starch as a capping biopolymer. ${ }^{27}$ The proposed mechanism, for starch-based synthesis of $\mathrm{CeO}_{2}-\mathrm{NPs}$ was that after dissolving starch in water, metal cations were attracted by oxygen of the $\mathrm{OH}$ branches. In vitro studies on Neuro2A cells demonstrated a dose-dependent toxicity with a nontoxic concentration of $175 \mu \mathrm{g} / \mathrm{mL}$. Applying starch as a template for $\mathrm{CeO}_{2}-\mathrm{NP}$ synthesis by Darroudi et $\mathrm{al}^{27}$ resulted in the formation of ultrafine $\mathrm{CeO}_{2}-\mathrm{NP}$ particles that were small in size and uniform in shape. Therefore, this method seems to be more appropriate for $\mathrm{CeO}_{2}-\mathrm{NP}$ synthesis for medical purposes. Furthermore, in line with the required characteristics, this method was found to be easy, economical and green for large-scale preparation of cerium oxide in nanoscale.

Regarding unique potential of biopolymers in the development of bio-directed methods of $\mathrm{CeO}_{2}-\mathrm{NP}$ synthesis, Darroudi et $\mathrm{al}^{27}$ also used Gum tragacanth (GT) for the production of $\mathrm{CeO}_{2}$-NPs by both chemical and biological methods. ${ }^{28}$ The soluble fraction (tragacanthin or tragacanthic acid) of GT gives a sol form in distilled water, whereas the insoluble fraction (bassorin) swells to a gel form (Figure 2). ${ }^{52,53}$ While heating the sol-gel solution up to $40^{\circ} \mathrm{C}$, the GT became soluble in water and the semicrystalline structures were lost. After adding the cerium nitrate to the solution, the metal cations were attracted by the oxygen of $\mathrm{OH}$ branches of GT polysaccharides. During the heating process, the amount of water was decreased and the nitrate decomposed to nitrogen dioxide and oxygen molecules, which were then removed from the compounds. $\mathrm{Ce}(\mathrm{OH})_{4}$ nuclei were converted into $\mathrm{CeO}_{2}$ nuclei via dehydration and, subsequently, highly crystallized $\mathrm{CeO}_{2}$-NPs particles grew. The required energy for the above reactions was provided by the subsequent sol-gel procedure and heat. The stabilizing effect of GT could be attributed to the steric repulsion force arising as the gum formed a layer around the cerium hydroxides and cerium oxide NPs. However, the ability of GT to stabilize $\mathrm{CeO}_{2}$-NPs might also be due to electrostatic interactions in addition to the enhancement of suspension viscosity. ${ }^{54,55}$ Although the formation of $\mathrm{CeO}_{2}$ NPs particles involved several complicated reactions, ${ }^{56}$ controlling the nucleation of initial precipitate $\mathrm{Ce}(\mathrm{OH})_{3}$ would mainly determine the properties of the final $\mathrm{CeO}_{2}-$ NPs. Furthermore, the $\mathrm{CeO}_{2}$-NPs exhibited very low cytotoxic effects on Neuro2A cell lines, making them suitable candidates for various biological applications. Dextran was also used for $\mathrm{CeO}_{2}$-NP stabilizing and coating, as it is a biocompatible, complex and highly watersoluble polysaccharide. ${ }^{57}$ Accordingly, NPs as small as $5 \mathrm{~nm}$ were produced which were toxic to cancer cells at $\mathrm{pH} 6$ and much less toxic to normal cells at the same $\mathrm{pH}$ value. ${ }^{57}$ Moreover, the importance and versatility of polyethylene glycol (PEG) for the functionalization of rare earth cerium oxide NPs were also investigated. ${ }^{58-60}$ The suggested mechanism for PEG-mediated ceria synthesis was the presence of an electrostatic driving force for the complexation. ${ }^{59}$ The branched structure of PEG is sufficient to solubilize the $\mathrm{CeO}_{2}$-NPs and create true dispersible nanopowders in aqueous solution and in certain organic solvents, providing a framework for designing a versatile hybrid metal oxide sol. ${ }^{58}$ Furthermore, chitosan-based synthesis of $\mathrm{CeO}_{2}-\mathrm{NPs}$ was also reported due to specific properties, such as good film-forming ability, biocompatibility, nontoxicity, biodegradability and antibacterial activity (Table 2). ${ }^{61,62}$ 


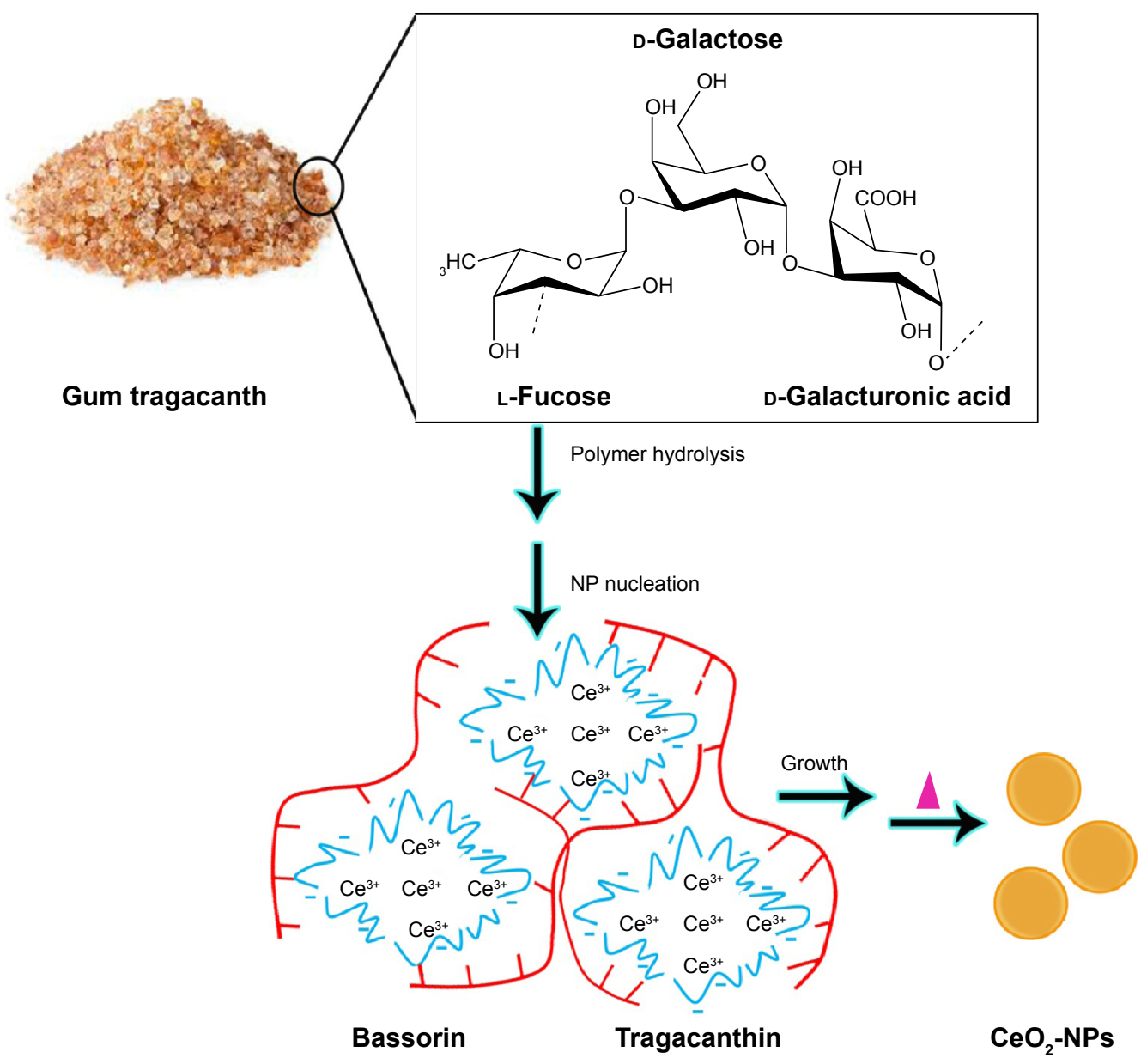

Figure 2 Schematic representation of the Gum base method of $\mathrm{CeO}_{2}-\mathrm{NP}$ synthesis. Abbreviation: $\mathrm{CeO}_{2}-\mathrm{NPs}$, cerium oxide nanoparticles.

\section{The toxicologic effect of green synthesized $\mathrm{CeO}_{2}-\mathrm{NPs}$}

All cerium oxide NPs contain the same core elements, however, do not display similar biological effects. There are some studies that reported prooxidant toxicity of NPs in some cases and antioxidant protective effects in others that could be attributed to different physiochemical parameters of the various NPs that were used. Method of NP synthesis, type of stabilizing agent used, and the $\mathrm{Ce}^{3+} / \mathrm{Ce}^{4+}$ surface ratio have been demonstrated to play major roles in producing $\mathrm{CeO}_{2}$-NPs with different physicochemical properties. ${ }^{63,64}$ The most important parameters are discussed below (Figure 3).

\section{Particle size}

Several green methods of $\mathrm{CeO}_{2}$-NPs synthesis have provided NPs as small as $<10 \mathrm{~nm}$. Previous results demonstrated that among different strategies reported for bio-directed synthesis of $\mathrm{CeO}_{2}$-NPs, biopolymer and nutrient-based methods provided the smallest NPs compared with plant-based processes. Reports indicated that plant-based $\mathrm{CeO}_{2}-\mathrm{NP}$ synthesis provided larger NP with antibacterial properties that exhibited high levels of cytotoxicity to bacterial cells. ${ }^{35,37}$ However, biopolymer- and nutrient-based methods have provided small NPs which show no cytotoxic effects to human cell lines at high concentrations of $\mathrm{CeO}_{2}-\mathrm{NPs}^{27,28,47,48,51}$

\section{Morphology}

Morphology is another physical property that is also required to be considered for biological applications. For example, NPs in polygonal, cube or rod shapes have sharp edges and could cause mechanical damage to cells. ${ }^{7,65,66}$ Therefore, the effect of NP shape cannot be ignored for biological applications. As mentioned earlier, almost all the green methods of ceria synthesis that are mentioned herein have produced NPs with spherical morphology. However, starch-based synthesis of $\mathrm{CeO}_{2}-\mathrm{NPs}$ seems to be the most appropriate method to provide $\mathrm{CeO}_{2}-\mathrm{NPs}$ for biomedical purposes. ${ }^{27}$ 
Table 2 Advantages and challenges of different methods of $\mathrm{CeO}_{2}-\mathrm{NPs}$ green synthesis

\begin{tabular}{|c|c|c|}
\hline Type of green method & Advantages & Disadvantages/challenges \\
\hline \multirow[t]{4}{*}{$\begin{array}{l}\text { Plant-mediated synthesis } \\
\text { of } \mathrm{CeO}_{2}-\mathrm{NPs}\end{array}$} & $\begin{array}{l}\text { Capable of generating spherical shaped NPs that } \\
\text { possessed reduced cytotoxicity }\end{array}$ & $\begin{array}{l}\text { Possibility of providing nonuniform morphology in some } \\
\text { case which could be attributed to agglomeration of the } \\
\text { individual NPs }\end{array}$ \\
\hline & $\begin{array}{l}\text { Easy process, cost-effectiveness, energy and time- } \\
\text { consuming technique }\end{array}$ & \\
\hline & & $\begin{array}{l}\text { Size of obtained NPs exhibited wide distribution } \\
\text { range from } 5 \text { to } 63.6 \mathrm{~nm} \text { using different bio-organisms } \\
\text { for synthesis }\end{array}$ \\
\hline & $\begin{array}{l}\text { Capable of producing stable, water dispersible and } \\
\text { highly fluorescent NPs }\end{array}$ & \\
\hline \multirow[t]{5}{*}{$\begin{array}{l}\text { Nutrient-mediated synthesis } \\
\text { of } \mathrm{CeO}_{2}-\mathrm{NPs}\end{array}$} & $\begin{array}{l}\text { Controllable growth and subsequent isotropic } \\
\text { formation of small and stable } \mathrm{CeO}_{2}-\mathrm{NPs}\end{array}$ & $\begin{array}{l}\text { Significant difference at the maximum concentration, } \\
\text { which was safe for the cells using EW }(800 \mu \mathrm{g} / \mathrm{mL}) \text { or } \\
\text { honey }(100 \mu \mathrm{g} / \mathrm{mL}) \text { as a stabilizing agents }\end{array}$ \\
\hline & Capable of providing spherical shaped $\mathrm{CeO}_{2}-\mathrm{NPs}$ & \\
\hline & Narrow distribution range of particle size & \\
\hline & Nontoxic effects of synthesized $\mathrm{CeO}_{2}-\mathrm{NPs}$ toward & \\
\hline & human cell lines at physiological concentrations of NPs & \\
\hline \multirow{6}{*}{$\begin{array}{l}\text { Biopolymer-mediated synthesis } \\
\text { of } \mathrm{CeO}_{2}-\mathrm{NPs}\end{array}$} & Generating NP with spherical morphology & \\
\hline & Providing NPs with no significant cytotoxic effect in & \\
\hline & human cell line at physiological concentrations & \\
\hline & Capable of controlling diameter of $\mathrm{CeO}_{2}-\mathrm{NPs}$ & \\
\hline & Providing NPs with high final purity & \\
\hline & Producing small $\mathrm{CeO}_{2}-\mathrm{NPs}$ & \\
\hline
\end{tabular}

Abbreviations: $\mathrm{CeO}_{2}-\mathrm{NPs}$, cerium oxide nanoparticles; $\mathrm{EW}$, egg white.

\section{Percentage of surface $\mathrm{Ce}^{3+}$}

In 2015, Pulido-Reyes et a ${ }^{67}$ presented a report that differed from previous reports about $\mathrm{CeO}_{2}$-NPs synthesis. They demonstrated that neither concentration, surface charge nor size of $\mathrm{CeO}_{2}$-NPs plays any important role in their observed toxic properties. The report demonstrated that percentage of surface $\mathrm{Ce}^{3+}$ correlated with toxicity and was the main driver of $\mathrm{CeO}_{2}-\mathrm{NPs}$ toxic effects. ${ }^{67}$ They proposed that $\mathrm{CeO}_{2}-\mathrm{NPs}$

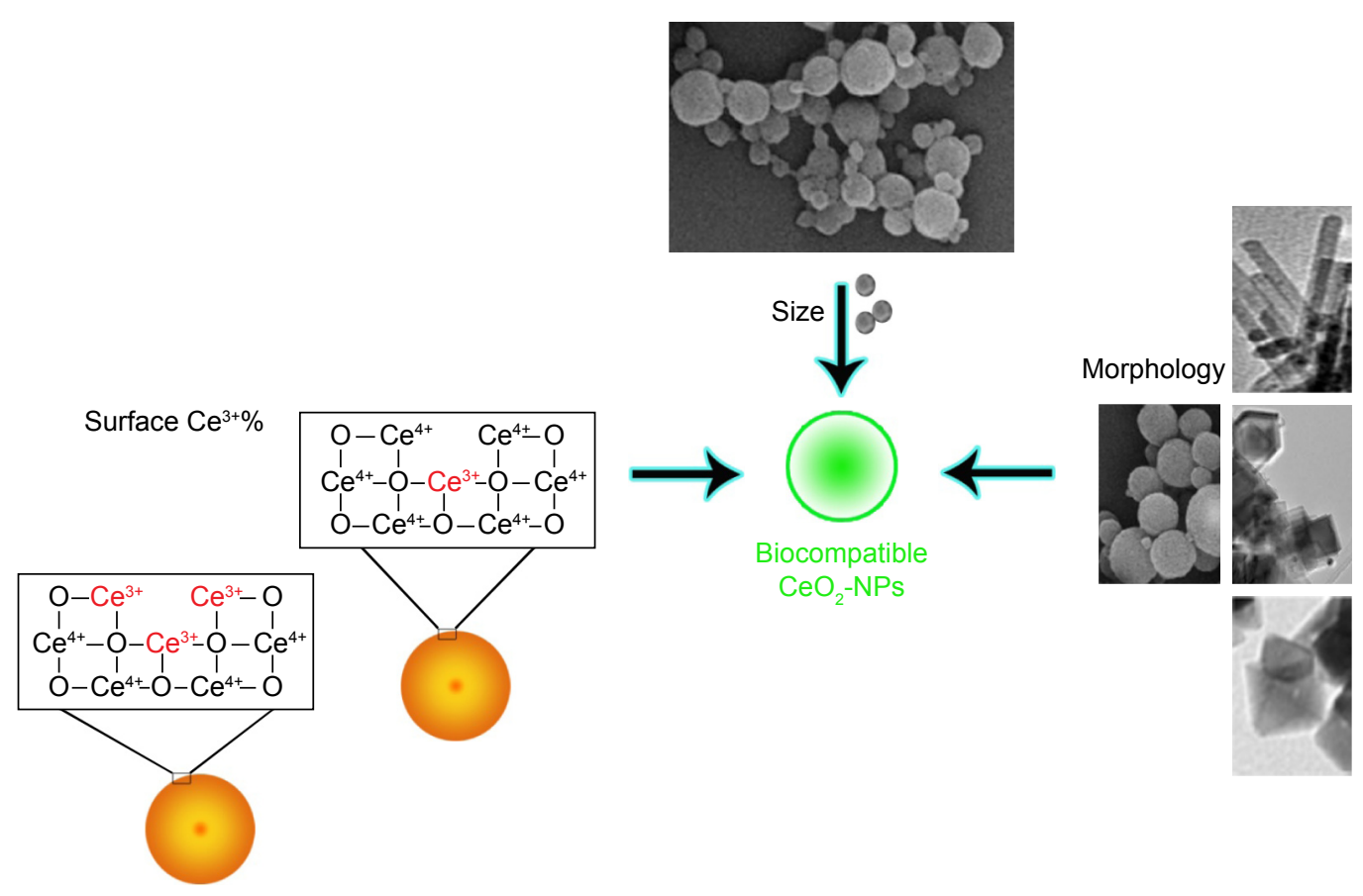

Figure 3 Major parameters affect the cytotoxicity of $\mathrm{CeO}_{2}-\mathrm{NPs}$.

Abbreviation: $\mathrm{CeO}_{2}-\mathrm{NPs}$, cerium oxide nanoparticles. 
with the highest percentage of surface $\mathrm{Ce}^{3+}(58 \%)$ exhibited the most toxic effect, and $\mathrm{CeO}_{2}$-NPs with lower percentage of surface $\mathrm{Ce}^{3+}$ values (between $26 \%$ and $36 \%$ ) were evidently nontoxic for the model organism. In fact, $\mathrm{CeO}_{2}-\mathrm{NPs}$ with lower $\mathrm{Ce}^{3+}$ and, therefore, higher $\mathrm{Ce}^{4+}$ on their surface showed catalase mimetic activity, ${ }^{68}$ which broke down $\mathrm{H}_{2} \mathrm{O}_{2}$ to molecular oxygen, protecting the cells against this toxic ROS. $\mathrm{CeO}_{2}$-NPs with higher $\mathrm{Ce}^{3+}$ on their surface could efficiently scavenge radicals of superoxide (superoxide dismutase [SOD] mimetic activity) and produce $\mathrm{H}_{2} \mathrm{O}_{2}$, which is toxic to the cells. They suggested that in a narrow range of surface $\mathrm{Ce}^{3+}$, there seemed to be a shift from SOD activity to catalase mimetic activity; however, the mechanisms and whether the observed biological effect reported at their study may also occur in other cellular systems, requires further investigation. ${ }^{67}$ However, there is no report on the effect of applying green methods of $\mathrm{CeO}_{2}$-NPs synthesis on the percentage of surface $\mathrm{Ce}^{3+}$ of NPs and this should be investigated to clearly demonstrate the effect of green synthesis of $\mathrm{CeO}_{2}-\mathrm{NPs}$ on their cytotoxicity.

$\mathrm{A} \mathrm{CeO}_{2}-\mathrm{NP}$ enters cells by energy-dependent, clathrinmediated and caveolae-mediated endocytic pathways. Its localization in mitochondria, lysosomes and endoplasmic reticulum, as well as the cytoplasm and nucleus, were demonstrated by Singh et al. ${ }^{69}$ Considering radical scavenging properties of cerium oxide and its widespread cellular disposition, a $\mathrm{CeO}_{2}$-NP likely acts as a cellular antioxidant in multiple compartments of the cell, presenting protection against a variety of oxidant injuries. ${ }^{69}$

\section{Biological applications of $\mathrm{CeO}_{2}-\mathrm{NPs}$ Antibacterial effect}

There are different studies that have reported antibacterial activity of $\mathrm{CeO}_{2}$-NPs and demonstrated their significant inhibition toward both gram-negative and gram-positive bacteria. ${ }^{34-37}$ It is suggested that $\mathrm{CeO}_{2}$-NPs with a particle size of over $20 \mathrm{~nm}$ possess antibacterial properties. Moreover, the most antibacterial effects due to the highest percentage of surface $\mathrm{Ce}^{3+}$ of NP are in agreement with Pulido-Reyes et al's observations. ${ }^{67}$

\section{Neurodegenerative effect}

The brain and central nervous system are the most active organ systems in the body; therefore, they are particularly sensitive to oxidative stress because of high oxygen utilization, high levels of polyunsaturated fatty acid peroxidation and low levels of endogenous antioxidant systems. Increased oxidative stress and free radical production could be attributed to several neurodegenerative diseases, such as Parkinson's disease, trauma, ischemic stroke, Alzheimer's disease (AD) and aging. ${ }^{70} \mathrm{~A}$ beneficial therapy for neurodegenerative diseases is $\mathrm{CeO}_{2}-\mathrm{NP}$ utilization, which removes ROS or prevents their formation and affects different key points in the brain cells or central nervous tissue. Reducing ROS production, $\mathrm{CeO}_{2}-\mathrm{NPs}$ were demonstrated to affect (directly or indirectly) signal transduction pathways involved in neuronal death and neuroprotection. For example, it is reported that cerium oxide NPs could trigger neuronal survival in a human AD model through modulating the brain-derived neurotrophic factor (BDNF) pathway. BDNF is a factor involved in the signal transduction pathways of neuronal survival. ${ }^{71}$ In a similar approach, Guo et al reported that ceria NPs protect neurons against oxidative stress induced injury by modulating transforming growth factor beta (TGF- $\beta$ ) signaling. ${ }^{72}$ There are so many reports on the neuroprotective effect of engineered $\mathrm{CeO}_{2}$-NPs. Recently, Arya et $\mathrm{al}^{3}$ reported that $\mathrm{CeO}_{2}-\mathrm{NPs}_{\text {s }}$ promoted neurogenesis and modulated hypoxia-induced memory impairment through the AMPK-PKCCBP signaling cascade. Using PEG-coated $3 \mathrm{~nm} \mathrm{CeO}_{2}-\mathrm{NPs}_{\text {, }}$ they demonstrated that NPs were efficiently localized in the brain and significantly decreased oxidative stress. Therefore, associated damage during hypoxia exposure was also reduced by applying PEG/CeO ${ }_{2}-\mathrm{NPs}$. They also provided evidence that $\mathrm{PEG} / \mathrm{CeO}_{2}$-NPs enhanced hippocampus neuronal survival and promoted neurogenesis. ${ }^{3}$

Regarding the reductive effect of $\mathrm{CeO}_{2}$-NPs on oxidative stress, which is known to play an important role in neurodegeneration, Fiorani et $\mathrm{al}^{73}$ had investigated the role of $\mathrm{CeO}_{2}-$ NPs on microglial activation and neurodegenerative processes in light damaged retina. They demonstrated the ability of $\mathrm{CeO}_{2}$-NPs to reduce microglial activation and their migration toward the outer nuclear layer, ${ }^{73}$ raising the possibility of their use as therapeutic agents for neurodegenerative diseases.

\section{Enzyme mimetic applications}

$\mathrm{CeO}_{2}-\mathrm{NPs}$ are forms of powerful artificial oxidase enzymes capable of mimicking catalase and SOD and peroxidase-like activities (Table 3).

Oxidase-like activity of these NPs originated from surface $\mathrm{Ce}^{3+}$ atoms as the catalytic center. ${ }^{74} \mathrm{CeO}_{2}-\mathrm{NPs}$ with lower $\mathrm{Ce}^{3+}$ on their surface showed catalase or peroxidase mimetic activity, ${ }^{68}$ which could break down $\mathrm{H}_{2} \mathrm{O}_{2}$ into water and oxygen. $\mathrm{CeO}_{2}-\mathrm{NPs}$ with higher $\mathrm{Ce}^{3+}$ on their surface could efficiently scavenge radicals of superoxide (SOD mimetic activity) and produce $\mathrm{H}_{2} \mathrm{O}_{2}$.

\section{SOD mimicking activity}

Comparing with natural enzymes, $\mathrm{CeO}_{2}$-NPs showed several advantages, such as high sensitivity, low cost, easy storage 
Table 3 Different types of enzyme mimicking activities of cerium oxide nanoparticles

\begin{tabular}{lll}
\hline Enzyme mimicking activities & Mechanism & References \\
\hline SOD & $M^{(n+1)+}-\mathrm{SOD}+\mathrm{O}_{2}^{-} \rightarrow \mathrm{M}^{n+}-\mathrm{SOD}+\mathrm{O}_{2}$ & 75,76 \\
& $\mathrm{M}^{n+}-\mathrm{SOD}+\mathrm{O}_{2}^{-}+2 \mathrm{H}^{+} \rightarrow \mathrm{M}^{(n+1)+}-\mathrm{SOD}+\mathrm{H}_{2} \mathrm{O}_{2}$ & $68,80,8 \mathrm{I}$ \\
Catalase & $\mathrm{H}_{2} \mathrm{O}_{2}+\mathrm{H}_{2} \mathrm{R} \rightarrow 2 \mathrm{H}_{2} \mathrm{O}+\mathrm{R}$ & 2 \\
Peroxidase & $R O O \mathrm{R}^{\prime}+2 \mathrm{e}^{-}+2 \mathrm{H}^{+} \rightarrow \mathrm{ROH}+\mathrm{R}^{\prime} \mathrm{OH}$ & \\
\hline
\end{tabular}

Abbreviation: SOD, superoxide dismutase.

and catalytic stability under harsh conditions. Construction of efficient artificial enzymes, as a strong and cost-effective alternative to natural enzymes, has been an interesting subject in the field of biomimetic chemistry. In a new report on SODlike activity of ceria, Bhushan and Gopinath ${ }^{75}$ developed a stable and biocompatible artificial enzymatic system based on $\mathrm{CeO}_{2}$-NPs that possessed high ROS scavenging activity over a period of time. They synthesized a $\mathrm{CeO}_{2}-\mathrm{NP}$ encapsulated biocompatible ceria-albumin nanoparticle (BCNP) capable of reducing intracellular ROS. The BCNPs preserved the antioxidant defense system of the cells and protected them from oxidant-mediated apoptosis. ${ }^{75}$ Importantly, the enzyme mimicking activity of $\mathrm{CeO}_{2}-\mathrm{NPs}$ remained almost constant and stable over a wide range of $\mathrm{pH}$ and temperature. Therefore, the as-prepared BCNPs were promising as potential candidates against ROS-induced diseases and disorders utilizing SOD-like activity of ceria. ${ }^{75}$ Moreover, the SOD ability of $\mathrm{CeO}_{2}-\mathrm{NPs}_{\mathrm{s}}$ with sizes $>5 \mathrm{~nm}$ and diversity in shape and a negligible $\mathrm{Ce}^{3+} / \mathrm{Ce}^{4+}$ ratio were also investigated by Li et al. ${ }^{76}$ So far, inherent superoxide-scavenging ability has only been found in the $\mathrm{CeO}_{2}$-NPs with sizes of $<5 \mathrm{~nm}$, and these bioactive $\mathrm{CeO}_{2}$-NPs showed very limited diversity with respect to shape. Li et al ${ }^{76}$ believed that without the coating of surface ligands to stabilize the oxygen vacancies, $\mathrm{CeO}_{2}-\mathrm{NPs}$ of $>3 \mathrm{~nm}$ could not maintain a substantially higher $\mathrm{Ce}^{3+} / \mathrm{Ce}^{4+}$ ratio under ambient conditions when compared to their bulk counterpart. ${ }^{77}$ Therefore, even $\mathrm{CeO}_{2}$-NPs of $<5 \mathrm{~nm}$ would lose their inherent SOD mimetic activity because of $\mathrm{Ce}^{3+}$ oxidation, and the time required to regenerate that activity would usually take days and weeks. ${ }^{78,79} \mathrm{Li}$ et al ${ }^{76}$ proposed a strategy to significantly improve the superoxide-scavenging activity of $\mathrm{CeO}_{2}-\mathrm{NPs}$ of $>5 \mathrm{~nm}$. However, they activated the SOD mimetic activity of different sized $\mathrm{CeO}_{2}-\mathrm{NPs}$ within minutes by incubation with native $\mathrm{CuZn-SOD}$ in phosphatebuffered saline (Figure 4$){ }^{76}$

\section{Catalase mimicking activity}

The first report on catalase mimicking activity of $\mathrm{CeO}_{2}-\mathrm{NPs}$ was presented by Pirmohamed et al. ${ }^{68}$ Recently, the catalytic activity of $\mathrm{CeO}_{2}$-NPs was applied in different biomedical approaches. ${ }^{80-82}$ For example, Akhtar et al have demonstrated that the catalase activity of $\mathrm{CeO}_{2}$-NPs could increase the intracellular glutathione (GSH) in cells challenged with $\mathrm{H}_{2} \mathrm{O}_{2}$, protecting cells from oxidative damage.${ }^{80}$ Considering major roles of GSH in the regulation of cell growth and division, metabolism of carcinogens and protecting DNA from oxidative damage, the effect of $\mathrm{CeO}_{2}-\mathrm{NPs}_{\text {s }}$ increasing the amount of intracellular GSH marks a revolution in medical biology. Moreover, Nicolini et al had introduced a kind of bioactive glass based on catalytic activity of $\mathrm{CeO}_{2}-\mathrm{NPs}$, which was used for bone tissue engineering. ${ }^{82}$ The design of bioactive glasses capable of preventing oxidative stress after implantation would reduce the convalescence and decrease the amount of anti-inflammatory responses in patients. Applying biomedical properties of $\mathrm{CeO}_{2}-\mathrm{NPs}$ requires more investigation of the NPs' fate in vivo. For example, cerium atoms of $\mathrm{CeO}_{2}$-NPs have the potential to interact with peptides, sugar and small anion molecules, such as phosphate in vitro and in vivo. Singh et al investigated the role of phosphate on stability and catalase mimetic activity of cerium oxide NPs. ${ }^{81,83}$ Given the abundance of inorganic phosphate in biological systems, they demonstrated that catalase mimetic activity of $\mathrm{CeO}_{2}$-NPs $\left(\mathrm{Ce}^{4+}\right)$ is resistant to the phosphate anions, $\mathrm{pH}$ changes and composition of cell culture media. Thus, Singh et al provided a promising approach to more practical and attractive biomedical applications for cerium oxide NPs.
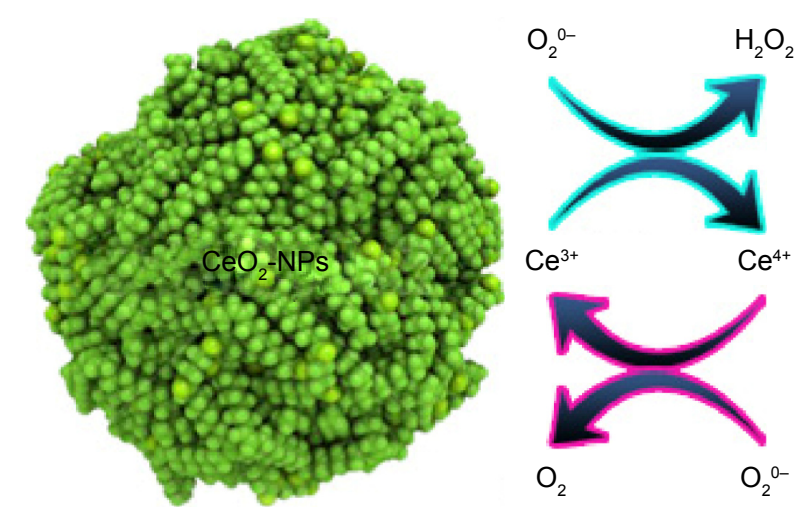

Figure 4 Superoxide dismutase mimetic activity of $\mathrm{CeO}_{2}$-nanoparticles. 


\section{Peroxidase mimicking activity}

SOD and catalase mimetic activity of $\mathrm{CeO}_{2}$-NPs has been studied extensively; however, research regarding its peroxidase-like activity remains scant. As the newest research in this field, Tian et al exploited the peroxidase-like activity of $\mathrm{CeO}_{2}$-NPs for breast cancer cell detection using nanostructure-based enzyme-linked immunosorbent assay (ELISA). ${ }^{2}$ In the designed system, the primary antibody against a biomarker of breast cancer (CA15-3) was coated on the ELISA plate and the second antibody was directly conjugated on the surface of $\mathrm{CeO}_{2}$-NPs through electrostatic forces. In the presence of cancer cells, the primary antibody could capture the cells and the secondary antibody-conjugated $\mathrm{CeO}_{2}-\mathrm{NPs}$ would attach to them, causing oxidation of $\mathrm{H}_{2} \mathrm{O}_{2}$ and color change. Comparing the $\mathrm{CeO}_{2}$-NPs-based sensor with the horse radish peroxidase (HRP)-based one, the high sensitivity of $\mathrm{CeO}_{2}$-NPs-based immunoassay, with a detection limit of $0.01 \mathrm{ng} / \mathrm{mL}$, was approximately one order of magnitude higher than the HRP system. ${ }^{2}$

\section{Sensing applications}

Different forms of biosensors were designed based on $\mathrm{CeO}_{2}-$ NPs, including electrochemical, fluorometric and colorimetric sensors, which are briefly discussed here. In 2006, the catalytic activity of cerium oxide NP was exploited to develop a highly sensitive biosensor for the first time. A study has shown that synthesized electrochemical biosensors based on cerium oxide NPs were efficient tools for $\mathrm{H}_{2} \mathrm{O}_{2}$ detection in as low as $1 \mu \mathrm{M}$ of water ${ }^{84}$ Currently, interfacing $\mathrm{H}_{2} \mathrm{O}_{2}$ with inorganic NPs has generated a number of nanozymes showing catalase or peroxidase-like activities. Recently, Liu et al ${ }^{85}$ introduced a $\mathrm{DNA} / \mathrm{CeO}_{2}$-NP-based fluorometric sensing system for highly sensitive detection of $\mathrm{H}_{2} \mathrm{O}_{2}$ (Figure 5). Liu et al probed $\mathrm{CeO}_{2}$-NPs and $\mathrm{H}_{2} \mathrm{O}_{2}$ interaction, applying DNA. $\mathrm{H}_{2} \mathrm{O}_{2}$ often causes oxidative DNA damage in the presence of redox metals; however, the ability of $\mathrm{H}_{2} \mathrm{O}_{2}$ to displace adsorbed DNA without cleavage was used in this study. After adding $\mathrm{CeO}_{2}$-NPs to the solution of fluorescently labeled DNA, the fluorescence was completely quenched, demonstrating the adsorption of DNA on the NPs' surface. Interestingly, fluorescence was completely and rapidly recovered after adding $\mathrm{H}_{2} \mathrm{O}_{2}$. Given the sensor performance for $\mathrm{H}_{2} \mathrm{O}_{2}$ with a detection limit of 130 $\mathrm{nM}$, Liu et al then tested the presence of glucose. $\mathrm{H}_{2} \mathrm{O}_{2}$ is produced in situ using glucose oxidase (GOX) and glucose. When the glucose concentration varied, a linear response was observed with a detection limit of $8.9 \mu \mathrm{M}$ in buffer and $4.37 \pm 0.32 \mathrm{mM}$ in serum..$^{85}$

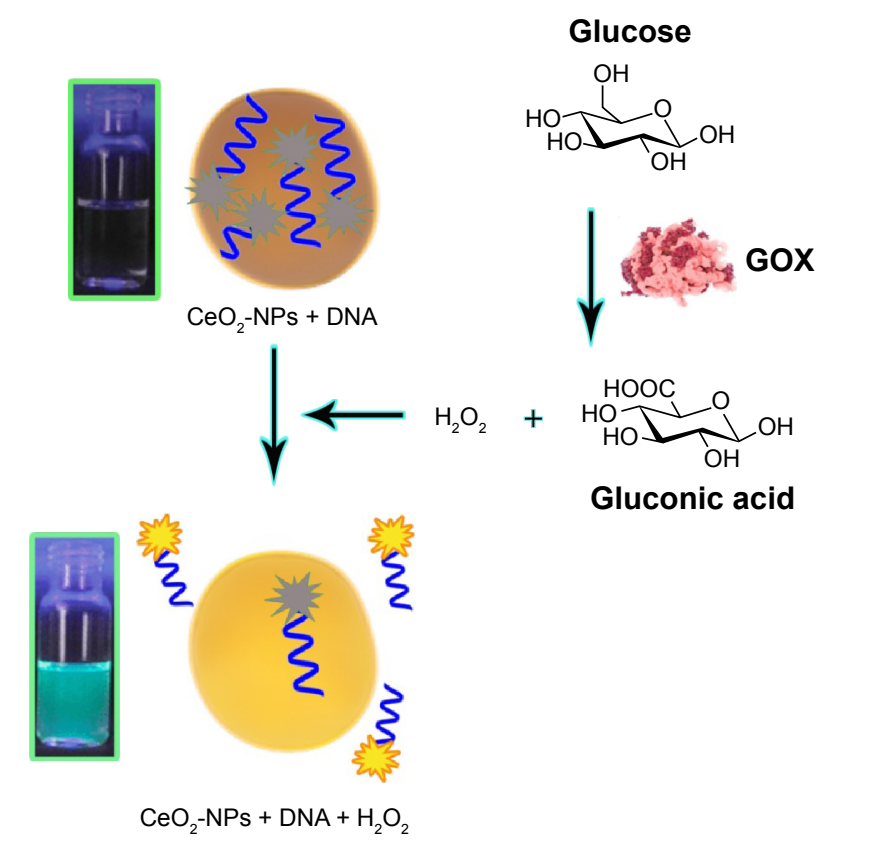

Figure $5 \mathrm{H}_{2} \mathrm{O}_{2}$ could make displacement of adsorbed DNA from $\mathrm{CeO}_{2}-\mathrm{NPs}$, resulting in fluorescence signal enhancement.

Abbreviation: $\mathrm{CeO}_{2}-\mathrm{NPs}$, cerium oxide nanoparticles.

In other work, Sardesai et al developed a biosensor based on oxygen-rich platinum doped $\mathrm{CeO}_{2}$-NPs (Pt-ceria) and lactate oxidase for in vitro and in vivo monitoring of lactate during hypoxia. ${ }^{86}$ Integration of the oxygen-rich $\mathrm{CeO}_{2}-\mathrm{NPs}$ in the enzyme-containing layer ensured operation of the biosensor in hypoxic conditions, and provided continuous, sensitive lactate monitoring. Measurements of lactate levels in blood and tissues are important indications of the state and progress of a variety of diseases. In vitro evaluation of the biosensor demonstrated a detection limit of $100 \mathrm{pM}$ and high selectivity against physiological levels of coexisting interference species, as well as a quick response time of 6 seconds. In vivo studies have been performed by placing the designed biosensor in the hippocampus of anesthetized rats. The results provided the possibility of continuous lactate monitoring under 2 hours ischemia and reperfusion. ${ }^{86}$ Moreover, all the mentioned reports have documented the ability of cerium oxide NPs to provide third-generation biosensors with high sensitivity and specificity of detection.

\section{Angiogenesis induction}

A unique property of $\mathrm{CeO}_{2}$-NPs could also induce angiogenesis in vivo. Angiogenesis is the physiological process through which new blood vessels form from pre-existing ones. In particular, $\mathrm{CeO}_{2}$-NPs trigger angiogenesis by modulating the intracellular oxygen environment and endogenously 
stabilizing hypoxia inducing factor $1 \alpha$, which alters gene regulation. Furthermore, the high surface area, increased $\mathrm{Ce}^{3+} / \mathrm{Ce}^{4+}$ ratio and small size make $\mathrm{CeO}_{2}-\mathrm{NPs}$ more catalytically active toward regulating intracellular oxygen, which in turn leads to more robust induction of angiogenesis. ${ }^{87}$

\section{Conclusion}

The unique property of $\mathrm{CeO}_{2}-\mathrm{NPs}$ that makes them distinct from other antioxidants is their ability to self-regenerate their surface. Thus, one small dose can work for a long time before being cleared from the body. ${ }^{7}$ Accordingly, various kinds of $\mathrm{CeO}_{2}$-NPs have been synthesized in order to target the Achilles' heel of any oxidative stress-associated diseases. ${ }^{88,89}$ Investigating previous literature on ceria NPs demonstrated that different synthesis methods could provide cerium oxide NPs with various catalytic and physiochemical properties that could contribute to antioxidant or prooxidant properties. ${ }^{29}$ Considering $\mathrm{CeO}_{2}$-NPs as potential therapeutic agents, it is important to pay attention to their synthesis method. Among different strategies reported for the synthesis of $\mathrm{CeO}_{2}-\mathrm{NPs}_{\text {, }}$ green synthesis methods have shown to be promising for $\mathrm{CeO}_{2}-\mathrm{NP}$ production and in their application in biological systems. Another consideration of $\mathrm{CeO}_{2}-\mathrm{NPs}_{\text {is }}$ that the in vitro measured properties of the NP (eg, zeta potential, size and redox activity) could change under physiological conditions. ${ }^{90}$ For example, Kumari et al has shown that the hydrodynamic diameter of $\mathrm{CeO}_{2}$-NPs increased dramatically in cell culture media due to the tendency of NPs to agglomerate in physiological conditions. ${ }^{91}$ Furthermore, adsorption of proteins in biological fluids, such as blood, could also affect the size and distribution of metal oxide NPs. Generally, smaller sized particles that are free of contamination are suitable for bioapplications. Using bio-directed methods, synthesis of small $\mathrm{CeO}_{2}$-NPs is possible. For example, as mentioned earlier, applying starch-based methods resulted in the production of $\mathrm{CeO}_{2}-\mathrm{NPs}$ as small as $6 \mathrm{~nm}$. Since bio-directed methods of $\mathrm{CeO}_{2}$-NP synthesis used biocompatible stabilizers and produced nontoxic NPs, of all the different methods of $\mathrm{CeO}_{2}-\mathrm{NP}$ synthesis, green synthesis is proposed to be applied for the production of $\mathrm{CeO}_{2}-\mathrm{NPs}$ for therapeutic purposes. Moreover, green synthesis of $\mathrm{CeO}_{2}$-NPs suggests several advantages, such as cost-effectiveness, large-scale commercial production and the potential for pharmaceutical applications.

\section{Future perspectives}

$\mathrm{CeO}_{2}$-NPs were recently shown to have regenerative antioxidant activity. Therefore, low levels of $\mathrm{CeO}_{2}$-NPs can work for extended time periods. However, these NPs provided some toxicologic concerns. Currently, the green synthesis of $\mathrm{CeO}_{2}$-NPs gets more attention in order to solve the challenges regarding safety and use of this metal oxide for biomedicine, but there are still some considerations. Previous reports suggested that the protein corona provides NPs with particular biological identity which subsequently play important roles in the ultimate interactions of NPs with target cells. Therefore, physiochemical characteristics of NPs after interaction with biological fluids should be investigated in order to achieve correct interpretations of the biocompatibility of green methods of $\mathrm{CeO}_{2}$-NPs synthesis. Moreover, regarding the effect of percentage of surface $\mathrm{Ce}^{3+}$ on the properties of $\mathrm{CeO}_{2}-\mathrm{NPs}$ in biological systems, the green synthesized $\mathrm{CeO}_{2}-\mathrm{NPs}$ should be investigated from this point of view. In addition, an important consideration in clinical usage of $\mathrm{CeO}_{2}-\mathrm{NPs}$ is how cerium oxide NPs behave in biological systems. Addressing this is not a simple endeavor and requires some in vivo-based research of the effect of $\mathrm{CeO}_{2}-\mathrm{NPs}$ produced by bio-directed methods.

\section{Disclosure}

The authors report no conflicts of interest in this work.

\section{References}

1. Gagnon J, Fromm KM. Toxicity and protective effects of cerium oxide nanoparticles (Nanoceria) depending on their preparation method, particle size, cell type, and exposure route. Eur J Inorg Chem. 2015;27: 4510-4517.

2. Tian Z, Li J, Zhang Z, Gao W, Zhou X, Qu Y. Highly sensitive and robust peroxidase-like activity of porous nanorods of ceria and their application for breast cancer detection. Biomaterials. 2015;59:116-124.

3. Arya A, Gangwar A, Singh SK, et al. Cerium oxide nanoparticles promote neurogenesis and abrogate hypoxia-induced memory impairment through AMPK-PKC-CBP signaling cascade. Int J Nanomedicine. 2016; 11:1159-1173.

4. Beaudoux X, Virot M, Chave T, Durand G, Leturcq G, Nikitenko SI. Vitamin C boosts ceria-based catalyst recycling. Green Chem. 2016;18: 3656-3668.

5. Gawande MB, Bonifacio VDB, Varma RS, et al. Magnetically recyclable magnetite-ceria (Nanocat-Fe-Ce) nanocatalyst - applications in multicomponent reactions under benign conditions. Green Chem. 2013;15(5): $1226-1231$.

6. Xu C, Qu X. Cerium oxide nanoparticle: a remarkably versatile rare earth nanomaterial for biological applications. NPG Asia Mater. 2014;6:e90.

7. Das S, Dowding JM, Klump KE, McGinnis JF, Self W, Seal S. Cerium oxide nanoparticles: applications and prospects in nanomedicine. Nanomedicine (Lond). 2013;8(9):1483-1508.

8. Deshpande S, Patil S, Kuchibhatla SV, Seal S. Size dependency variation in lattice parameter and valency states in nanocrystalline cerium oxide. Appl Phys Lett. 2005;87(13):133113.

9. Asati A, Santra S, Kaittanis C, Nath S, Perez JM. Oxidase-like activity of polymer-coated cerium oxide nanoparticles. Angew Chem Int Ed Engl. 2009;48(13):2308-2312.

10. Asati A, Kaittanis C, Santra S, Perez JM. The pH-tunable oxidase-like activity of cerium oxide nanoparticles achieves sensitive fluorigenic detection of cancer biomarkers at neutral pH. Anal Chem. 2011;83(7): $2547-2553$. 
11. Li X, Sun L, Ge A, Guo Y. Enhanced chemiluminescence detection of thrombin based on cerium oxide nanoparticles. Chem Commun. 2011; 47(3):947-949.

12. Kaittanis C, Santra S, Asati A, Perez JM. A cerium oxide nanoparticlebased device for the detection of chronic inflammation via optical and magnetic resonance imaging. Nanoscale. 2012;4(6):2117-2123.

13. Ornatska M, Sharpe E, Andreescu D, Andreescu S. Paper bioassay based on ceria nanoparticles as colorimetric probes. Anal Chem. 2011;83(11): 4273-4280.

14. Lin Y, Xu C, Ren J, Qu X. Using thermally regenerable cerium oxide nanoparticles in biocomputing to perform label-free, resettable, and colorimetric logic operations. Angew Chem Int Ed Engl. 2012;51(50): 12579-12583.

15. Celardo I, Pedersen JZ, Traversa E, Ghibelli L. Pharmacological potential of cerium oxide nanoparticles. Nanoscale. 2011;3(4): 1411-1420.

16. Li M, Shi P, Xu C, Ren J, Qu X. Cerium oxide caged metal chelator: anti-aggregation and anti-oxidation integrated $\mathrm{H}_{2} \mathrm{O}_{2}$-responsive controlled drug release for potential Alzheimer's disease treatment. Chem Sci. 2013;4(6):2536-2542.

17. Xu C, Lin Y, Wang J, et al. Nanoceria-triggered synergetic drug release based on $\mathrm{CeO} 2$-capped mesoporous silica host-guest interactions and switchable enzymatic activity and cellular effects of CeO2. Adv Healthc Mater. 2013;2(12):1591-1599.

18. Chen HI, Chang HY. Synthesis of nanocrystalline cerium oxide particles by the precipitation method. Ceramics Int. 2005;31(6):795-802.

19. Yu JC, Zhang L, Lin J. Direct sonochemical preparation of high-surfacearea nanoporous ceria and ceria-zirconia solid solutions. J Colloid Interface Sci. 2003;260(1):240-243.

20. Yan Z, Wang J, Zou R, Liu L, Zhang Z, Wang X. Hydrothermal synthesis of $\mathrm{CeO} 2$ nanoparticles on activated carbon with enhanced desulfurization activity. Energy Fuels. 2012;26(9):5879-5886.

21. Chunwen S, Hong L, Huairuo Z, Zhaoxiang W, Liquan C. Controlled synthesis of $\mathrm{CeO} 2$ nanorods by a solvothermal method. Nanotechnology. 2005;16(9):1454.

22. Yadav TP, Srivastava ON. Synthesis of nanocrystalline cerium oxide by high energy ball milling. Ceramics Int. 2012;38(7):5783-5789.

23. Wang Y, Mori T, Li JG, Ikegami T. Low-temperature synthesis of praseodymium-doped ceria nanopowders. J Am Ceramic Soc. 2002; 85(12):3105-3107.

24. Feng X, Sayle DC, Wang ZL, et al. Converting ceria polyhedral nanoparticles into single-crystal nanospheres. Science. 2006;312(5779): 1504-1508.

25. Hirano M, Fukuda Y, Iwata H, Hotta Y, Inagaki M. Preparation and spherical agglomeration of crystalline cerium(IV) oxide nanoparticles by thermal hydrolysis. J Am Ceramic Soc. 2000;83(5):1287-1289.

26. He HW, Wu XQ, Ren W, Shi P, Yao X, Song ZT. Synthesis of crystalline cerium dioxide hydrosol by a sol-gel method. Ceramics Int. 2012; 38(Suppl 1):S501-S504.

27. Darroudi M, Sarani M, Kazemi Oskuee R, Khorsand Zak A, Hosseini HA Gholami L. Green synthesis and evaluation of metabolic activity of starch mediated nanoceria. Ceramics Int. 2014;40(1, Part B): 2041-2045.

28. Darroudi M, Sarani M, Kazemi Oskuee R, Khorsand Zak A, Amiri MS. Nanoceria: gum mediated synthesis and in vitro viability assay. Ceramics Int. 2014;40(2):2863-2868.

29. Dowding JM, Seal S, Self WT. Cerium oxide nanoparticles accelerate the decay of peroxynitrite $\left(\mathrm{ONOO}^{-}\right)$. Drug Deliv Transl Res. 2013;3(4): 375-379.

30. Dowding JM, Das S, Kumar A, et al. Cellular interaction and toxicity depend on physicochemical properties and surface modification of redox-active nanomaterials. ACS Nano. 2013;7(6):4855-4868.

31. Adschiri T, Lee YW, Goto M, Takami S. Green materials synthesis with supercritical water. Green Chem. 2011;13(6):1380-1390.

32. Ko JW, Lee BI, Chung YJ, Park CB. Carboxymethyl cellulosetemplated synthesis of hierarchically structured metal oxides. Green Chem. 2015;17(8):4167-4172.
33. Arumugam A, Karthikeyan C, Haja Hameed AS, Gopinath K, Gowri S, Karthika V. Synthesis of cerium oxide nanoparticles using Gloriosa superba L. leaf extract and their structural, optical and antibacterial properties. Mater Sci Eng C Mater Biol Appl. 2015;49:408-415.

34. Kannan SK, Sundrarajan M. A green approach for the synthesis of a cerium oxide nanoparticle: characterization and antibacterial activity. Int $J$ Nanosci. 2014;13(03):1450018.

35. Priya GS, Kanneganti A, Kumar KA, Rao KV, Bykkam S. Bio synthesis of cerium oxide nanoparticles using Aloe arbadensis Miller Gel. Int J Sci Res Publications. 2014;4(6):1-4.

36. Kumar A, Das S, Munusamy P, et al. Behavior of nanoceria in biologicallyrelevant environments. Environ Sci Nano. 2014;1(6):516-532.

37. Munusamy S, Bhakyaraj K, Vijayalakshmi L, Stephen A, Narayanan V. Synthesis and characterization of cerium oxide nanoparticles using Curvularia lunata and their antibacterial properties. Int J Innovative Res Sci Eng. 2014;2(1):318-323.

38. Thill A, Zeyons O, Spalla O, et al. Cytotoxicity of $\mathrm{CeO} 2$ nanoparticles for Escherichia coli. Physico-chemical insight of the cytotoxicity mechanism. Environ Sci Technol. 2006;40(19):6151-6156.

39. Zeyons O, Thill A, Chauvat F, et al. Direct and indirect $\mathrm{CeO} 2$ nanoparticles toxicity for Escherichia coli and Synechocystis. Nanotoxicology. 2009;3(4):284-295.

40. Rodea-Palomares I, Gonzalo S, Santiago-Morales J, et al. An insight into the mechanisms of nanoceria toxicity in aquatic photosynthetic organisms. Aquat Toxicol. 2012;122-123:133-143.

41. Hoecke KV, Quik JTK, Mankiewicz-Boczek J, et al. Fate and effects of $\mathrm{CeO} 2$ nanoparticles in aquatic ecotoxicity tests. Environ Sci Technol. 2009;43(12):4537-4546.

42. Rogers NJ, Franklin NM, Apte SC, et al. Physico-chemical behaviour and algal toxicity of nanoparticulate $\mathrm{CeO} 2$ in freshwater. Environ Chem. 2010;7(1):50-60.

43. Rodea-Palomares I, Boltes K, Fernández-Piñas F, et al. Physicochemical characterization and ecotoxicological assessment of $\mathrm{CeO} 2$ nanoparticles using two aquatic microorganisms. Toxicol Sci. 2011; 119(1):135-145.

44. Xia T, Kovochich M, Liong M, et al. Comparison of the mechanism of toxicity of zinc oxide and cerium oxide nanoparticles based on dissolution and oxidative stress properties. ACS Nano. 2008;2(10): 2121-2134.

45. Zhao L, Peng B, Hernandez-Viezcas JA, et al. Stress response and tolerance of Zea mays to $\mathrm{CeO} 2$ nanoparticles: cross talk among $\mathrm{H}_{2} \mathrm{O}_{2}$, heat shock protein, and lipid peroxidation. ACS Nano. 2012; 6(11):9615-9622.

46. Mohanpuria P, Rana NK, Yadav SK. Biosynthesis of nanoparticles: technological concepts and future applications. J Nanopart Res. 2007;10(3):507-517.

47. Kargar H, Ghazavi H, Darroudi M. Size-controlled and bio-directed synthesis of ceria nanopowders and their in vitro cytotoxicity effects. Ceramics Int. 2015;41(3, Part A):4123-4128.

48. Darroudi M, Hoseini SJ, Kazemi Oskuee R, Hosseini HA, Gholami L, Gerayli S. Food-directed synthesis of cerium oxide nanoparticles and their neurotoxicity effects. Ceramics Int. 2014;40(5):7425-7430.

49. Singh AV, Bandgar BM, Kasture M, Prasad BLV, Sastry M. Synthesis of gold, silver and their alloy nanoparticles using bovine serum albumin as foaming and stabilizing agent. J Mater Chem. 2005;15(48): 5115-5121.

50. Darroudi M, Ahmad MB, Abdullah AH, Ibrahim NA. Green synthesis and characterization of gelatin-based and sugar-reduced silver nanoparticles. Int J Nanomedicine. 2011;6:569-574.

51. Kargar H, Ghasemi F, Darroudi M. Bioorganic polymer-based synthesis of cerium oxide nanoparticles and their cell viability assays. Ceramics Int. 2015;41(1, Part B):1589-1594.

52. Loth F. Industrial Gums: Polysaccharides and Their Derivatives. 3rd edition. Edited by Roy L. Whistler and James N. BeMiller. ISBN 0-12746253-8. Academic Press, Inc., San Diego/New York/Boston/London/ Sidney/Tokyo/Toronto 1993.642P. Acta Polymerica. 1993;44(3): $172-173$. 
53. Davidson RL. Handbook of Water-Soluble Gums and Resins/Robert L. Davidson, editor in chief. New York, NY: McGraw-Hill; 1980.

54. Remani KC, Ghosh S. Nanocrystalline ceria through homogeneous precipitation in alcohol-water mixed solvent. Trans Indian Ceramic Soc. 2009;68(4):185-188.

55. Yokoyama A, Srinivasan KR, Fogler HS. Stabilization mechanism of colloidal suspensions by gum tragacanth: the influence of $\mathrm{pH}$ on stability. J Colloid Interface Sci. 1988;126(1):141-149.

56. Khorsand Zak A, Abd Majid WH, Mahmoudian MR, Darroudi M, Yousefi R. Starch-stabilized synthesis of $\mathrm{ZnO}$ nanopowders at low temperature and optical properties study. Adv Powder Technol. 2013; 24(3):618-624.

57. Alpaslan E, Yazici H, Golshan NH, Ziemer KS, Webster TJ. pHdependent activity of dextran-coated cerium oxide nanoparticles on prohibiting osteosarcoma cell proliferation. ACS Biomater Sci Eng. 2015;1(11):1096-1103.

58. Qi L, Fresnais J, Mullera P, Theodoly O, Berretb F, Chapel P. Interfacial activity of phosphonated-polyethylene glycol functionalized cerium oxide nanoparticles. Langmuir. 2012;28(31):11448-11456.

59. Qi L, Sehgal A, Castaing JC, et al. Redispersible hybrid nanopowders: cerium oxide nanoparticle complexes with phosphonated-PEG oligomers. ACS Nano. 2008;2(5):879-888.

60. Satapathy S. PEG-Assisted Synthesis and Characterization of Ceria Nanoparticles. Rourkela, India: National Institute of Technology; 2011.

61. Kaushik A, Solanki PR, Pandey MK, Ahmad S, Malhotra BD. Cerium oxide-chitosan based nanobiocomposite for food borne mycotoxin detection. Appl Phys Lett. 2009;95(17):173703.

62. Hassannejad H, Nouri A. Synthesis and evaluation of self-healing cerium-doped chitosan nanocomposite coatings on AA5083-H321. Int J Electrochem Sci. 2016;11:2106-2118.

63. Karakoti A, Singh S, Dowding JM, Seal S, Self WT. Redox-active radical scavenging nanomaterials. Chem Soc Rev. 2010;39(11):4422-4432.

64. Alili L, Sack M, von Montfort C, et al. Downregulation of tumor growth and invasion by redox-active nanoparticles. Antioxid Redox Signal. 2013; 19(8):765-778.

65. Dahle J, Arai Y. Environmental geochemistry of cerium: applications and toxicology of cerium oxide nanoparticles. Int J Environ Res Public Health. 2015;12(2):1253-1278.

66. Prabaharan DMDM, Sadaiyandi K, Mahendran M, Sagadevan S. Structural, optical, morphological and dielectric properties of cerium oxide nanoparticles. Mater Res. 2016;19(2):478-482.

67. Pulido-Reyes G, Rodea-Palomares I, Das S, et al. Untangling the biological effects of cerium oxide nanoparticles: the role of surface valence states. Sci Rep. 2015;5:15613.

68. Pirmohamed T, Dowding JM, Singh S, et al. Nanoceria exhibit redox state-dependent catalase mimetic activity. Chem Commun. 2010;46(16): 2736-2738.

69. Singh S, Kumar A, Karakoti A, Seal S, Self WT. Unveiling the mechanism of uptake and sub-cellular distribution of cerium oxide nanoparticles. Mol Biosyst. 2010;6(10):1813-1820.

70. Uttara B, Singh AV, Zamboni P, Mahajan RT. Oxidative stress and neurodegenerative diseases: a review of upstream and downstream antioxidant therapeutic options. Curr Neuropharmacol. 2009;7(1):65-74.

71. D’Angelo B, Santucci S, Benedetti E, et al. Cerium oxide nanoparticles trigger neuronal survival in a human Alzheimer disease model by modulating BDNF pathway. Curr Nanosci. 2009;5(2):p167.

72. Guo C, Smith R, Gant TW, Leonard MO. Cerium dioxide nanoparticles protect against oxidative stress induced injury through modulation of TGF- $\beta$ signalling. Toxicol Res. 2015;4(2):464-475.
73. Fiorani L, Passacantando M, Santucci S, Di Marco S, Bisti S, Maccarone R. Cerium oxide nanoparticles reduce microglial activation and neurodegenerative events in light damaged retina. PLoS One. 2015;10(10):e0140387.

74. Juarez R, Corma A, Garcia H. Gold nanoparticles promote the catalytic activity of ceria for the transalkylation of propylene carbonate to dimethyl carbonate. Green Chem. 2009;11(7):949-952.

75. Bhushan B, Gopinath P. Antioxidant nanozyme: a facile synthesis and evaluation of the reactive oxygen species scavenging potential of nanoceria encapsulated albumin nanoparticles. J Mater Chem B. 2015; 3(24):4843-4852.

76. Li Y, He X, Yin JJ, et al. Acquired superoxide-scavenging ability of ceria nanoparticles. Angew Chem Int Ed Engl. 2015;54(6):1832-1835.

77. Zhang D, Wen X, Shi L, Yan T, Zhang J. Enhanced capacitive deionization of graphene/mesoporous carbon composites. Nanoscale. 2012;4(17): $5440-5446$

78. Heckert EG, Karakoti AS, Seal S, SelfWT. The role of cerium redox state in the SOD mimetic activity of nanoceria. Biomaterials. 2008;29(18): 2705-2709.

79. Karakoti AS, Singh S, Kumar A, et al. PEGylated nanoceria as radical scavenger with tunable redox chemistry. J Am Chem Soc. 2009;131(40): 14144-14145.

80. Akhtar MJ, Ahamed M, Alhadlaq HA, Khan MA, Alrokayan SA. Glutathione replenishing potential of $\mathrm{CeO} 2$ nanoparticles in human breast and fibrosarcoma cells. J Colloid Interface Sci. 2015;453:21-27.

81. Singh R, Singh S. Role of phosphate on stability and catalase mimetic activity of cerium oxide nanoparticles. Colloids Surf B Biointerfaces. 2015;132:78-84.

82. Nicolini V, Gambuzzi E, Malavasi G, et al. Evidence of catalase mimetic activity in $\mathrm{Ce} 3+/ \mathrm{Ce} 4+$ doped bioactive glasses. $J$ Phys Chem B. 2015;119(10):4009-4019.

83. Singh S, Dosani T, Karakoti AS, Kumar A, Seal S, Self WT. A phosphate-dependent shift in redox state of cerium oxide nanoparticles and its effects on catalytic properties. Biomaterials. 2011;32(28): 6745-6753.

84. Patil SD. Fundamental Aspects of Regenerative Cerium Oxide Nanoparticles and Their Applications in Nanobiotechnology [dissertation]. Florida, USA: Department of Mechanical, Materials and Aerospace Engineering University of Central Florida; 2006.

85. Liu B, Sun Z, Huang PJJ, Liu J. Hydrogen peroxide displacing DNA from nanoceria: mechanism and detection of glucose in serum. $J \mathrm{Am}$ Chem Soc. 2015;137(3):1290-1295.

86. Sardesai NP, Ganesana M, Karimi A, Leiter JC, Andreescu S. Platinumdoped ceria based biosensor for in vitro and in vivo monitoring of lactate during hypoxia. Anal Chem. 2015;87(5):2996-3003.

87. Das S, Singh S, Dowding JM, et al. The induction of angiogenesis by cerium oxide nanoparticles through the modulation of oxygen in intracellular environments. Biomaterials. 2012;33(31):7746-7755.

88. Estevez AY, Erlichman JS. Cerium oxide nanoparticles for the treatment of neurological oxidative stress diseases. Oxidative Stress: Diagnostics, Prevention, and Therapy. Vol 1083: New York: American Chemical Society; 2011:255-288.

89. Andreescu S, Hepel M. Oxidative Stress: Diagnostics, Prevention, and Therapy. Vol. 1083. ACS Symposium Series. New York: American Chemical Society; 2011.

90. Estevez AY, Erlichman JS. The potential of cerium oxide nanoparticles (nanoceria) for neurodegenerative disease therapy. Nanomedicine (Lond). 2014;9(10):1437-1440.

91. Kumari M, Singh SP, Chinde S, Rahman MF, Mahboob M, Grover P. Toxicity study of cerium oxide nanoparticles in human neuroblastoma cells. Int J Toxicol. 2014;33(2):86-97. 
International Journal of Nanomedicine

Dovepress

\section{Publish your work in this journal}

The International Journal of Nanomedicine is an international, peerreviewed journal focusing on the application of nanotechnology in diagnostics, therapeutics, and drug delivery systems throughout the biomedical field. This journal is indexed on PubMed Central, MedLine, CAS, SciSearch $®$, Current Contents $® /$ Clinical Medicine,
Journal Citation Reports/Science Edition, EMBase, Scopus and the Elsevier Bibliographic databases. The manuscript management system is completely online and includes a very quick and fair peer-review system, which is all easy to use. Visit http://www.dovepress.com/ testimonials.php to read real quotes from published authors.

Submit your manuscript here: http://www.dovepress.com/international-journal-of-nanomedicine-journal 